Provided for non-commercial research and education use. Not for reproduction, distribution or commercial use.

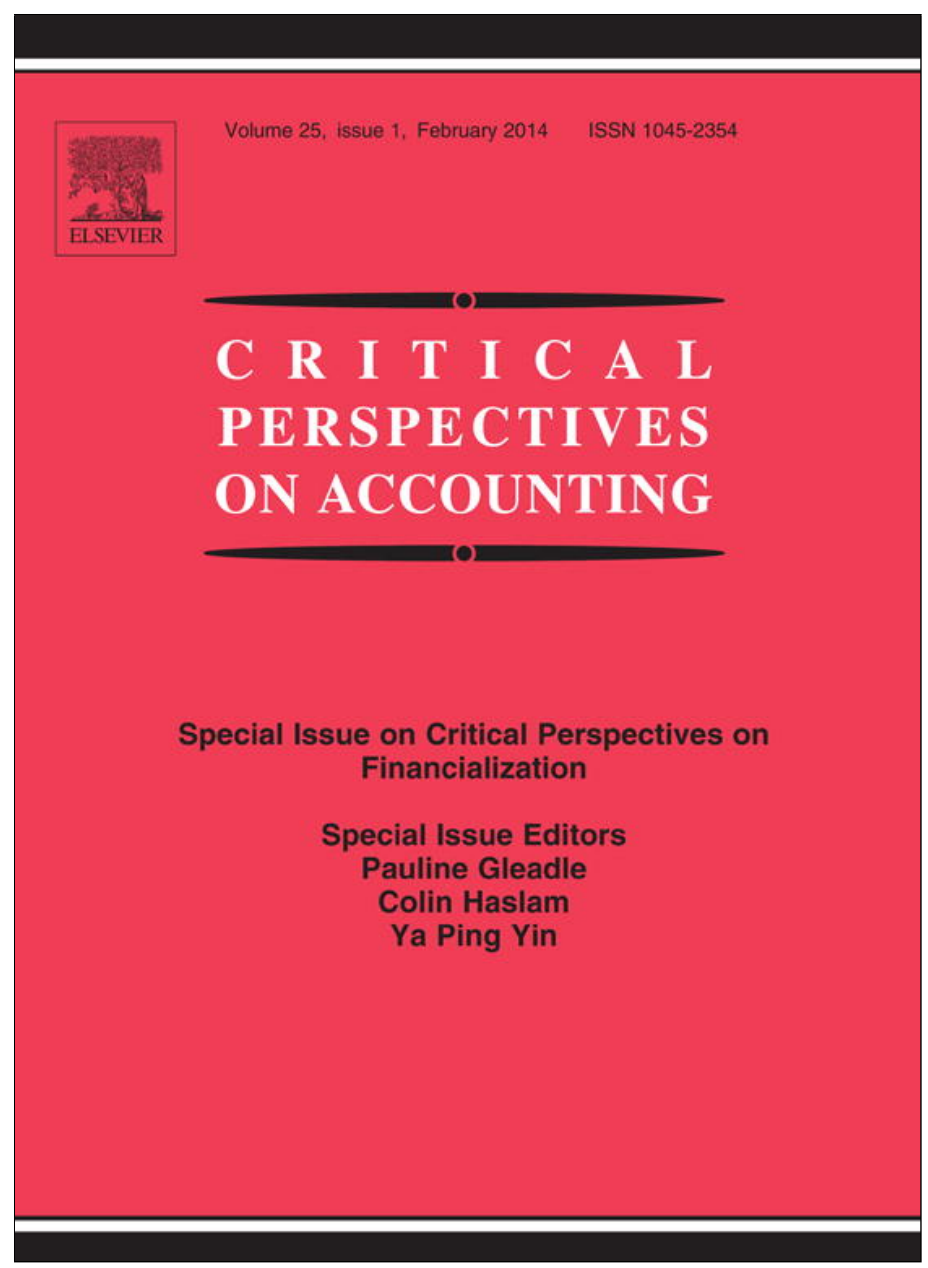

This article appeared in a journal published by Elsevier. The attached copy is furnished to the author for internal non-commercial research and education use, including for instruction at the authors institution and sharing with colleagues.

Other uses, including reproduction and distribution, or selling or licensing copies, or posting to personal, institutional or third party websites are prohibited.

In most cases authors are permitted to post their version of the article (e.g. in Word or Tex form) to their personal website or institutional repository. Authors requiring further information regarding Elsevier's archiving and manuscript policies are encouraged to visit:

http://www.elsevier.com/authorsrights 


\title{
Situating financial literacy
}

\author{
Charlotta Bay ${ }^{\mathrm{a}, *}$, Bino Catasús ${ }^{\mathrm{b}, \mathrm{c}}$, Gustav Johed ${ }^{\mathrm{b}}$ \\ ${ }^{a}$ Department of Business Studies, Uppsala University, Box 513, SE-751 20 Uppsala, Sweden \\ ${ }^{\mathrm{b}}$ School of Business, Stockholm University, SE-106 91 Stockholm, Sweden \\ ${ }^{\mathrm{c}}$ Norwegian School of Economics, Bergen, Norway
}

\section{A R T I C L E I N F O}

\section{Article history:}

Received 30 September 2011

Received in revised form 22 August 2012

Accepted 1 October 2012

Available online 20 December 2012

\section{Mots clés:}

Critique

Enseignement de la comptabilité

Palabras clave:

Crítica

Educación contable

Keywords:

Critical

Accounting education

Financial literacy

Financialisation

Financial education

Audit committees

New Literacy Studies

\begin{abstract}
A B S T R A C T
This paper comments on the conceptualisation of financial literacy by investigating how it is defined, problematised, and operationalised as a part of the efforts to overcome its perceived impediments. The backdrop of this study is the idea that the financial literacy movement goes hand in hand with the financialisation of society. By reporting from a study of financial literacy practices, the aim is to disentangle the notion of financial literacy from the assumption that it is a singular capability that, when gained, will automatically affect people's financial practices. The paper draws on a recent development in literacy research, New Literacy Studies, and on its division into autonomous and ideological definitions of literacy. The empirical illustrations originate from the efforts made to decrease financial illiteracy among Swedish adolescents and the demand for financial literacy in audit committees. Contrary to earlier studies, this paper demonstrates that financial literacy does not merely refer to a character trait that researchers may find lacking among the marginalised actors in society. Financial literacy cannot merely be viewed as the ability to read and write in the language of finance and accounting. Instead, financial literacy is a concept that needs to be situated and studied in practice because the characteristics that constitute financial literacy, or those that apply to it, vary with time and place.
\end{abstract}

(c) 2012 Elsevier Ltd. All rights reserved.

\section{Introduction}

A recent report from the International Organization of Securities Commissions (IOSCO) concludes as follows:

No matter what disclosures are mandated, they will not have the intended effect if the investor either does not read and/or understand the information provided. Regulators should therefore consider measures to help improve retail investor education in order to enhance their financial literacy and ability to read investment documentation and make informed investment decisions (IOSCO, 2009, principle 6).

Contrary to IASB and FASB's solution to improve market efficiency by demanding increased disclosure, IOSCO (2009) qualifies the problem of information efficiency as the inability of investors to accurately understand financial information. This state of affairs is described as an obstacle that needs to be overcome. This conclusion is not limited to IOSCO, however. Parallel with the financialisation of society (Epstein, 2005; Finlayson, 2009; Froud et al., 2002; Martin, 2002), actors including The World Bank (2009), the $\operatorname{OECD}(2005,2006,2008,2009)$ and the European Commission (2007) have all concluded that

\footnotetext{
* Corresponding author. Tel.: +46 704829495.

E-mail addresses: charlotta.bay@fek.uu.se (C. Bay), bino.catasus@fek.su.se (B. Catasús), gustav.johed@fek.su.se (G. Johed).
} 
financial literacy programmes need to be initiated. The reports are univocal in their conclusion: the level of financial knowledge needs to be raised so that non-professional investors can act in a financially responsible manner.

Increased financial literacy is believed to not only prevent negative impacts on the financial markets (cf. IOSCO, 2009) but to also contribute to improving corporate governance. According to Williams (2007) "[l]iterate, skilled consumers are expected to search the market effectively, monitor firms attentively, switch providers efficiently, and exercise their consumer power to drive out of the market firms that are dishonest, incompetent, or indifferent to consumers' needs" (p. 233). Thus, financially literate actors drive both efficient markets and effective corporations.

The problem of financial literacy, however, does not reside only among the non-professional investors. Although the higher level employees in organisations are implicitly expected to possess this capability, the recent financial crises illustrate that the risks of investing in and accounting for new financial products was understood neither by the professional investors nor by the firms. As a response to the diminishing level of trust (Finansinspektionen, 2009), financial literacy has also become an issue for boards of directors, with questions as to whether the accounting and auditing "scandals" would have occurred if the boards of directors had been sufficiently competent. Consequently, the issue of financial literacy is of concern both inside and outside of the organisation.

There are three research traditions concerned with financial literacy (Almenberg and Widmark, 2011). The first tradition seeks to measure the level of financial literacy in different demographic areas (Almenberg and Widmark, 2011; Huston, 2010; Jappelli, 2010; Lusardi and Mitchell, 2007). The second tradition investigates the effects of financial literacy on financial decisions (Almenberg and Widmark, 2011; Carter, 1973; Johnson and Sherraden, 2007; Lusardi and Mitchell, 2007; Van Rooij et al., 2007). The third tradition studies the effects of financial education. A central debate in the latter theme is whether financial illiteracy can be overcome (Fox et al., 2005; Lyons et al., 2006; Oehler and Werner, 2008; The World Bank, 2009; Willis, 2009). Taken together, the research addressing financial literacy suggests that (1) there is a delineated and stable notion of financial literacy; (2) the financial skills underlying the notion of literacy predict how the individual will make financial decisions; and (3) by being taught how to acquire and foster these skills, a financially incapable person can become a capable investor (Langley, 2008).

This paper questions this line of argument. The aim is to disentangle the notion of financial literacy from the assumption of a singular capability that, when gained, automatically affects people's financial practices. By examining how financial literacy is configured in the private as well as the corporate sphere, this paper demonstrates that financial literacy is not primarily about possessing the skills to interpret accounting and financial information. Rather, what constitutes financial literacy changes when different social settings are considered.

To emphasise the context-bound meaning of financial literacy, this paper draws on two cases of financial literacy discourse in Sweden. These cases both share the goal of raising the literacy level, although in different areas of society. The first case examines financial education for high-school students. This case offers an opportunity to witness how financial literacy is configured in a setting in which the financially illiterate are predominantly consumers and describes a situation in which young people lack the ability to manage their personal finances. The second case examines board work in public companies and the companies' efforts to include a financially literate person in their audit committees (hereafter, ACs). The committee members' level of financial literacy came into increased public focus after the scandals in the beginning of the century (Benston and Hartgraves, 2002). Although the relationship between an AC's effectiveness and the financial literacy of the AC has been questioned (Gendron and Bédard, 2006; Turley and Zaman, 2007), financial literacy became a regulatory concern in the EU with the 8th Directive (European Commission, 2006). This paper takes on these two cases to analyse a concept that has become a benchmark for progress in the financialisation of society.

This paper provides an account of a strand of literature labelled New Literacy Studies (NLS). NLS represents a broadened view of how to understand literacy, which, in terms of this paper, offers theoretical arguments for analysing our data. This paper continues by describing how the data were collected and coded, followed by an analysis of the two cases. The conclusions about the results are presented in the final section of the paper, accompanied by a discussion of how this study contributes to defining areas that are appropriate for further research into how financial literacy interplays with the consumption of accounting information.

\section{Financial literacy from a new (literacy) perspective}

Beginning with the basics, the Collins Dictionary states that literacy refers to

The ability to read and write; the ability to use language effectively. ${ }^{1}$

This definition encapsulates the dominant (and common-sense) idea about literacy, which also suggests that literacy is something desirable. According to Gee (2008), this attitude towards literacy is related to the belief that literate people make up a modern and civilised society. Being modern and civilised then provides an empowering ability (Freire and Macedo, 1987) that allows individuals to think rationally and to take critical stances (Gee, 2008). These positive attributes are assumed to be components of higher social equity (ibid.) because high literacy rates are associated with democratised societies. In this tradition, literacy is a practice that can be mastered through the acquisition of the right skills and that, to a

\footnotetext{
${ }^{1}$ http://www.collinsdictionary.com/dictionary/english/literacy (24 February 2012).
} 
limited degree, is affected by ideology (Gee, 2008; Gough, 1995). Thus, the arguments follow a linear "literacy-comes-first" logic (Rogers, 2001, p. 206) where the expected outcome is progress.

In the 1980s, however, the authors that promoted the concepts that would eventually be labelled the "New Literacy Studies" (Barton and Hamilton, 2000; Gee, 1990; Street, 1984) began to reject this traditional "read and write" definition that was based on a proxy for competence. Their argument was that the previous understanding of literacy downplayed the social setting in which literacy is observed (Gee, 2008). Their critique did not ignore literacy practices but argued that literacy is situated within a particular time of history and in relation to specific social practices (Gee, 2008, 2000). Street (1997) labelled this dominant form of literacy studies (Clarke, 2002) as autonomous because it builds on the assumption that literacy in itself - autonomously - will have effects on other social practices. Street's $(1997,2003)$ critique of the autonomous perspective is twofold: it overlooks that neither illiteracy nor literacy appears outside of the social context and that to disregard such a context is to ignore that literacy is more than a set of individual cognitive achievements (see also Gee, 2000, 2008).

Against the autonomous perspective, Street (1997) advocates an ideological model of literacy. In a nutshell, the ideological model means that what counts as literate differs "from culture to culture and from period to period" (Jackson, 1993, p. 2); in other words, the understandings of literacy result from analysis rather than from autonomous definitions. This model suggests that a literate person is someone who reads a particular type of text at a particular time and, moreover, does it in a particular way (Gee et al., 1996).

Literacy is not just a set of 'technical skills' to be imported to those lacking them (...) but rather that there are multiple literacies in communities and that literacy practices are socially embedded. (Street, 2001, p. 2)

This acknowledgement suggests that an actor's literacy interacts with the social setting. As a corollary, different forms of literacy co-exist and compete in society (Gee et al., 1996), and the concept of literacy should include representational forms beyond the written word. However, the ideological model does not question the existence of illiteracy, but rather the definitions, methods and effects of the literacy efforts:

Social consequences are assumed to follow from literacy, such as 'modernisation', 'progress' and economic rationality to name a few. Recent research, however has challenged this 'autonomous' view'. (Street, 1996, p. 2)

Although the distinction between an autonomous and an ideological model of literacy is relevant to the financial literacy discourse, the concept of ideology might lead us to believe that the autonomous model lacks ideology. This paper argues, however, that a model that suggests that a technology is neutral and can be unaffected by application in time and space is ideological per se. That argument is certainly consistent with the thrust of NLS, which argues that the autonomous model disguises ideological assumptions (Street, 1996). In the following, the ideological model is re-labelled as a situated model of literacy (see, e.g., Ahrens and Chapman, 2007; Bay, 2011a, 2011b).

Applied to financial literacy, the distinction between the autonomous and the situated models is that the former makes it possible to delineate financial literacy without taking into effect how, when and toward whom the literacy event is directed. This type of model offers measures to divide actors into financial literates and illiterates. Understood in this way, an autonomous model can identify and act upon illiteracy. In a recent review, Remund (2010) summarised various definitions of financial literacy and classified them into five categories:

(1) Knowledge of financial concepts

(2) Ability to communicate about financial concepts

(3) Aptitude in managing personal finances

(4) Skill in making appropriate financial decisions

(5) Confidence in planning effectively for future financial needs

Remund's classification summarises the thrust of the financial literacy movement, in which "literacy comes first" (Rogers, 2001). That is, in the autonomous model it is possible to (1) diagnose financial illiteracy and (2) perform financial literacy events so that (3) the financially illiterate become financially literate. This view has been contested by several reviews, however. For example, Atkinson (2008) concludes that "there is little in the way of robust evidence to show the overall effect of financial training" (p. 5). However, Atkinson concludes that this lack of evidence might be an effect of evaluation methods such as the small size of the studies, poor indicators of financial literacy, and data and estimation issues. In another review, de Meza and colleagues (2008), rooted in the behavioural economics stream of research, state that the norms affecting financial behaviour impede the success of financial education. Rather, it is the situated financial literacy activities (such as personal intervention by a counsellor or individualised advice) that can make a change. The conclusion is that even though a situated model of financial literacy cannot offer the same type of measurable results for the level of literacy, the model offers us narratives of how financial literacy is constituted in practice.

To sum up, the New Literacy Studies have taken a social turn away from a focus on the inherent to the affected, from skills to practices, from cognitive dispositions to cultural conditions. This view of literacy is based on the idea that reading and writing practices only make sense when they are studied within their context-a context of which they are but a part. "In its simplest sense", as Barton and Hamilton (2000) put it, "literacy practices are what people do with literacy" (p. 7). This concept entails the recognition of multiple types of literacy. As such, literacy events are historically and contextually situated and always embedded in broader goals that serve overarching purposes. 


\section{Design of study}

Material addressing how financial illiteracy is attended to in high schools was collected from multiple sources. Archival material was gathered from reports produced by the OECD, the EU, and IOSCO, as well as by the Swedish regulatory authorities such as the Financial Markets Advisory Committee (FMAC) and the Financial Supervisory Authority (FSA). The first author also conducted ten interviews with civil servants and political advisors at the FMAC, the FAS, the Enforcement Authority (EA), the Consumer Agency (CA) and the Ministry of Finance. The interviewing started in February 2008 and ended in March 2009. The length of the interviews varied between one and two hours. The interviews were semi-structured, including a set of open-ended questions for the interviewees to elaborate on. Seven of the ten interviews were recorded. The high-school tour, conducted during September-November 2008, comprised twenty-four stops in cities in Sweden. The first author participated on four occasions, observing the activities in class. Most of the activities performed illustrated the arguments in a film produced to form a point of departure for the student discussion in class. The film, together with the teacher instruction manual that was produced to support interaction with students, constituted additional sources of information for the analysis.

The material for the AC case is gathered from two sources. First, a variety of texts were examined such as corporate governance codes and governance regulations. The investigation was directed towards recounting how financial literacy is recognised in these texts. Second, the case uses 41 interviews with board members of public companies. Interviewing started in 2010 and ended in June 2011; on average the interviews lasted $90 \mathrm{~min}$, and all but six were recorded. The issue of financial literacy was raised when the respondents described the relationship between the board, the AC and the auditor. The interviews with board members provided us with an opportunity to analyse how notions of literacy are connected to ACs and board practices.

The entire data set was organised by creating a scrapbook of quotations related to elaborations of financial literacy. The coding was informed by a methodological key concept of NLS studies denoted literacy events (Barton and Hamilton, 2000; Street, 2001). Literacy events refer to episodes where observable elements related to financial literacy can be identified and described, such as interacting participants, texts and activities performed by participants (Hamilton, 2000). Applied to our cases, this definition means describing events where the activities that are derived from an understanding of financial literacy are operationalised by the different actors. Literacy events arise from literacy practices (Barton and Hamilton, 2000; Street, 2001), which is the second methodological principle. Literacy practices sensitise literacy events by connecting them to a social context (Street, 2001).

\section{Situating financial literacy - two cases}

\subsection{Financial literacy from a financial education perspective}

In a press release, the Swedish Minister for Financial Markets Mats Odell states that (2007)

It's high time for us to identify the knowledge gaps and do our best to support and strengthen the households' ability to manage their personal finances. Only then will we get the savvy consumers the Swedish financial sector deserves and needs to face tougher competition. That, I believe, is a challenge that ultimately will benefit us all.

This press release marked the start of the Swedish financial education programme, ${ }^{2}$ which aims to instruct Swedish citizens how to become financially capable. The programme grew to incorporate a network of public authorities and organisations under the umbrella name of the National Assembly for Increased Financial Self-Confidence. The programme launch came after a decade-long international debate about alleviating financially distressed consumers (OECD, 2005, pp. 62-64). According to the report, financial distress at the private level resulted from changing economic and political conditions, and the altered pension systems and the increased complexity of financial products demand an enhanced level of financial awareness from the individual. The OECD concludes that without appropriate measures to rectify financial literacy, a substantial number of citizens will end up in financial isolation (OECD, 2005). Financial literacy events are, thus, defined by the ambition of including people in a social setting of financial norms.

The Swedish programme was initiated by surveying 1000 households on two occasions, $2007^{3}$ (Finansinspektionen, 2007) and $2009^{4}$ (Finansinspektionen, 2009). The criteria used in the surveys correspond to Remund's (2010) definition of financial literacy as competence in managing money. The survey measured this competence implicitly, indicating an autonomous financial literacy norm against which all people might be objectively compared and evaluated. Because the questionnaires were developed to measure people's attitudes towards their own financial affairs, it allowed for the identification of archetypes, such as "the spender" or "the typical less-informed person" (Finansinspektionen, 2007, pp. 8-

\footnotetext{
${ }^{2}$ Several national financial education programmes have been launched internationally. For detailed country information, see the OECD website http:// www.financial-education.org (8 August 2012).

3 The survey was conducted by the Financial Supervisory Authority.

4 The survey was commissioned by the Financial Supervisory Authority and executed by the private contractor Svenskt Kvalitetsindex and EDB Business Partner.
} 
37). The construction of these categories indirectly helped to further clarify the meaning of "financially literate", although by delineating what it not rather than what it is.

In $2010,{ }^{5}$ a third survey was carried out to measure the population's mastery of numbers and financial concepts. The survey executors acknowledged that numeracy and financial literacy are difficult to differentiate. Even so, it was concluded that financial literacy, understood as a knowledge-based resource involving "familiarity with financial concepts and products", is determined and supported by the individual's level of numeracy, referring to a skill-based cognitive ability "to process numerical information and perform simple calculations” (Almenberg and Widmark, 2011, p. 2, 7). Accordingly, it was suggested that financial illiteracy could be indirectly alleviated by raising the level of numeracy (Almenberg and Widmark, 2011). Moreover, when market participation was evaluated based on these two measures, the findings resulted in the identification of yet another autonomous relationship. The authors found that increased numerical capability leads to increased financial literacy, which in turn leads to increased activity in the stock markets (ibid.) - all resonating with the "literacy-comes-first argument" (Rogers, 2001).

The Swedish surveys were based on measures from similar international surveys (cf. Banks and Oldfield, 2007; Lusardi and Mitchell, 2007, 2006) indicating that financial literacy is seen as a non-situated issue. The Swedish surveys found, consistent with their international counterparts, that many adults struggle with basic calculations and lack an understanding of elementary financial concepts. It is noteworthy that it was considered normal and consistent with expectations to find that older people performed below average. This conclusion implies that not only can we expect financial literacy to change over a life span but also that this change is acceptable. The financial illiteracy among young people is spelled out as particularly worrying, however. Furthermore, the illiteracy found in this group also held consequences for how to direct the literacy initiative:

The results should be used for preventive efforts aimed to improve financial ability where it has been shown weak. By replicating the survey on a regular basis, e.g., annually, the effect of these efforts can be measured. (Finansinspektionen, 2007, p. 2).

As a result of the link between numeracy and financial literacy outlined above, financial illiteracy became a problem that could be identified, directly acted upon, and solved. Consequently, the conducted surveys were concerned with identifying the deviant areas where financial capabilities were absent and with characterising these absences as symptoms of a financial illiteracy problem that needs to be solved. Because the financial illiteracy problem was outlined as originating from deficient individual abilities, developing these skills follows naturally as a solution. In the autonomous model outlined in the third survey (Almenberg and Widmark, 2011), an increased level of numeracy would the level of interest that people take in financial issues.

From the surveys, it was established that financial illiteracy among the younger generation was especially worrying, so three public authorities ${ }^{6}$ decided to go on a high-school tour in 2008 . The tour's goal was to get young people to reflect upon their financial choices as a way to empower these students to make wise decisions in the future (Finansinspektionen et al., 2008). At the schools, the tour representatives introduced a teaching package that described the issues to think about when starting up a life for oneself. The reasons for the poor survey performance of these young people were discussed during an interview with one of the tour organisers:

I think it's not just a matter of economy. You have to see the bigger picture here. (...) It's not just a matter of money. Apart from the money, there are loads of other mechanisms contributing to a higher consumption pressure which in turn has effects on the budget, which in turn might put you in a position of over-consumption.

According to the organisers, financial education directed towards students cannot, initially, be about financial products or setting up budgets. The organisers concluded that rather than introducing high-school students to stocks and bonds or showing them how to work out interest rates, the financial education of young people should primarily be concerned with their attitudes towards money. Hence, a generic skill-based competency was contested and became, instead, re-defined into a concern for their every-day practice. This decision corresponds to the NLS argument that, in contrast with the autonomous model of financial literacy where the definition dictates the terms for the reader, the situated model considers the social setting to determine how that same definition should be practised (Street, 2001). As a corollary, financial literacy is dependent on the particular setting, and, in the following, two examples illustrate how literacy practices were translated into the classroom.

A central exercise at the schools asked the students to participate in "value exercises". Value exercises are scenarios where the students are confronted with ethical dilemmas that are potentially related to their own lives. In one such scenario, the students encountered a hypothetical situation where there is a festival that they want to attend that they cannot afford. Students are then asked to choose one of three options:

(a) stay at home,

(b) borrow money from their parents or take a small credit loan, or

(c) work at the festival for free.

\footnotetext{
5 The survey was commissioned by the Financial Supervisory Authority and executed by the private contractor Svenskt Kvalitetsindex.

${ }^{6}$ The FSA, the EA and the CA.
} 
According to the organisers, the purpose of this exercise was not to tell students how to make the "right" decision but to force them to reflect on how they individually reach financial decisions, giving them an opportunity to examine the pros and cons that these decisions entail. The point made is that turning students into financially literate citizens always begins with an awareness of how they choose to relate to themselves and their current financial situation. Moreover, in the teaching kit handed out to the teachers, a publication called "If. . . I had only known" was included. This information folder is co-produced by the Swedish Tax Authority and forms part of a campaign that tries to affect the problem of payment defaults among young people. The information in this folder includes a series of questions formulated as idioms or metaphors that have many possible answers:

- What happens when you're in debt up to your ears but with no money to pay?

- Does advertising create indebted people?

The folder aims to initiate a self-dialogue that recognises the financial issues at stake. As a side product to the folder, a rapsong was also produced. ${ }^{7}$ Consistent with the NLS arguments (e.g., Street, 1997), financial literacy extends beyond the written domain and therefore efforts aimed at affecting financial literacy include various mediating tools and practices. This financial education model is organised around practices that enable financially illiterate youth to reflect on the financial issues that are found in their own domain. This detour connects popular culture with the financial issues that occur in the context of a young person's life. The situated model of financial literacy, i.e., the model that was used in practice in the highschool tour, is not characterised by developing numerical skills or by teaching financial vocabulary (in its narrow sense). Rather, this financial literacy endeavour asks the participants to reflect on their role in society and to consider the necessity of a practice in which financial competence is a given.

On the one hand, the autonomous model is used to identify financial illiteracy because a norm of literacy enables the deviations to be spotted. Deviations from this norm can then be used by the regulatory agencies to pinpoint the financially illiterate groups in society and to justify efforts to remedy the financial shortcomings among those groups. On the other hand, when efforts are made to overcome financial illiteracy for a certain strata of society, these efforts are adjusted to a highly specific notion of financial literacy; hence, they represent a type of situated model of financial literacy.

\subsection{Financial literacy from an audit committee perspective}

The prominence of the audit committee has changed over the years. The early demands of the AC were limited, and it was not until the mid-1980s that the AC began to be given responsibilities that extended beyond their relationship with the auditor (Verschoor, 2008). The demands on the AC have been generated by a mix of laws, banking crises and initiatives from other stakeholders (ibid.). In a comment regarding the lack of competence at Worldcom, Micklethwait (2006) finds that "of its four members, only two had formal financial training” (p. 71), implying that with training, the AC's decisions would have been better aligned with the public interest.

Financial literacy became a regulatory concern with the Blue Ribbon Committee report (Blue Ribbon Committee, 1999) that recommended that every public company should have an AC comprising at least three financially literate members. ${ }^{8}$ The committee defined financial literacy as "the ability to read and understand fundamental financial statements, including a company's balance sheet, income statement, and cash flow statement" (ibid., chapter 3). Interestingly, the report distinguished between being "financially literate" and being an "expert". In the report (ibid.) they suggest that an AC should be "comprised of a minimum of three directors, each of whom is financially literate. . . and further ... at least one member of the audit committee [should] have accounting or related financial management expertise." Thus, financial literacy varies not only within the board (AC vs. the rest of the board), but it also varies within the AC (expert vs. financially literate).

Unlike the Blue Ribbon report, the EU's 8th Directive did not demand three financially literate members of the AC but only one. In response to the proposed law, the consultation bodies raised several problematic aspects. Most specifically, the demand that one AC member have competence in accounting and auditing spurred the question 'How can we recognise this competence?' In contrast to the Blue Ribbon report, the Directive did not qualify the term financial literacy. In Sweden, the critique from the Swedish Board of Corporate Governance forced the government to clarify the term financial literacy:

...the ... requirement must be determined in light of the circumstances of the individual company.... There are no demands for formal education in accounting or auditing. Instead, the understanding of such issues can come with the experience of senior management. This must be decided on a case-by-case basis. If a person, for example, has held a position as CEO, with responsibilities for accounting and financial management associated with this mission, this should be adequate experience to meet the requirement of the necessary accounting skills (Govt. 2008/09: 135, p. 155).

In effect, to be financially literate in an AC setting, the person could have practised financial competence in other contexts. This definition implies that this competence can only be gained outside of the AC. That is, a member of the AC who is not considered to be financially literate cannot become literate by serving on the AC. Here, the autonomous model of financial

\footnotetext{
7 The rap-song is available at http://www.youtube.com/user/iffe23\#p/a/u/2/5jAcRBxNAeY (15 July 2011).

8 The report had an impact, and in 1999, the NYSE added financial literacy to its listing requirements.
} 
literacy implies that literacy is equated with outside experience. The practical implication is that to act upon the level of literacy, the board can only become more literate by recruiting new board members.

Our interviews revealed that one desired competence of a non-executive director was prior experience as a CEO. The board members argue that without such experience, one cannot "see through the accounts":

Since I have been a CEO for such a long time ... I know how the CEO may present the performance so that the reports show what is expected. Sometimes a CEO might be tempted to avoiding highlighting problems.

Hence, the implication is that financial literacy in the AC is the ability to read what is not there, i.e., to read between the lines. A financially literate person is a person who has the capability to contextualise the financial report. Thus, one needs to be able to understand the author of the reports, which, in turn, means that the reader of the financial report expects the author to have the ability to whitewash these financial texts. Lurking behind such a statement is an ideology of self-interest in which the CEO will, if needed and if possible, use the AC's financial illiteracy to obtain benefits. At the same time, if the readers think like the author, the $A C$ might too easily accept the dominant financial discourse. One interviewee without financial expertise (but with an academic degree in social science) framed his lack of specific financial expertise as an advantage:

When I am asked about my academic degrees ... I always say that it has given me confidence to ask stupid questions. And, as we all know, these are often the ones that lead us forwards.

This quote illustrates that it is possible to be too literate, according to an autonomous definition, and that ignorance may indeed be warranted. Another of our respondents, resonating with a respondent in Gendron and Bédard's (2006) study, questioned the direct relationship between financial literacy and qualified decisions:

My competitive advantage is that I can pose the stupid questions that are needed to see through the technological jargon that sometimes characterises board work.

Even though a recent review of AC effectiveness indicates that the measures of financial expertise have a positive association with AC effectiveness (Bédard and Gendron, 2010), this association has not been established for financial literacy, arguably because it has not been widely used as a proxy for AC effectiveness. Rather, and as indicated by the two quotes above, the assumption that a high level of financial literacy equals effective governance should not be taken for granted. As discussed in the prior literature on ACs, a structural characteristic of an AC such as having a non-executive director who is financially literate is not necessarily related to improved control or to the AC's effectiveness (see, e.g., Gendron and Bédard, 2006; Turley and Zaman, 2007).

The analysis the meaning of literacy in an AC introduces a challenge for the autonomous view. First, because the definition of financial literacy is in flux, it is difficult to discover who is literate. Second, because experience is at the core of as the definition of financial literacy in the AC and because experience cannot be taught, the financially illiterate remain illiterate. Third, there is an acknowledged risk that the AC may become too financially literate (sic!) and that this state might impede both control and creativity. A plausible explanation to the advent of these challenges is that while financial literacy is a rhetorical strategy in our first case, functioning as a means to initiate a programme, it needs to be practicably operationalised in the context of a committee.

\section{Concluding discussion}

The distinct ways in which financialisation (Epstein, 2005) is said to be manifested in society has emerged in the prior literature as an effect of the societal level from which it is studied. On the global level, for example, financialisation relates to issues such as financial innovations on the capital market (McSweeney, 2009). In a similar vein, the national level is central to Belfrage's (2008) analysis of how states manage new pension systems. Furthermore, financialisation has been studied and connected to internal corporate strategies and management orientation (Andersson et al., 2010; Gleadle and Haslam, 2010; Lazonick and O'Sullivan, 2000). In addition, the individual level has been central in studies of how individuals manage and are affected by their private investments, pensions, mortgages, and credit card expenditures, etc. (e.g., Greenfield and Williams, 2007; Langley, 2007, 2008; Martin, 2002). However, this paper argues that the prior studies have overlooked the relationship between financial literacy and financialisation, i.e., how the framing of financial literacy, irrespective of the societal level, bears on how financialisation is understood and practised. The benefit of analysing financial literacy is that it is required at multiple levels of society and as such offers an empirical opportunity to detail the different ways in which it enables the influence of the capital market to shape local practices. In the following, three findings are highlighted regarding how financial literacy unfolds and is configured.

First, by illustrating two separate approaches to financial literacy, i.e., the financial education case and the regulation of the audit committee, this paper demonstrates that financial literacy is by no means a stable concept that is drawn upon in one particular setting for one particular purpose. The finding that financial (il)literacy is mobilised in different situations implies that the concept is both stable, transportable and elastic, harbouring several understandings and areas of application. More specifically, this paper has demonstrated that financial literacy is seen either as (1) an individual capability that can be acted upon in relation to experience, vocabulary and skills (the autonomous model), or (2) a socially situated issue where financial literacy in itself must always be debated (the situated model). 
Table 1

Summary of findings.

\begin{tabular}{|c|c|c|c|}
\hline When the problem is defined as & ...efforts entail & ...which is characterised by & $\ldots$ and is illustrated in the case of \\
\hline Absent literacy & Literacy construction & Inclusion of actors & Survey/high-school tour \\
\hline Present literacy & Literacy recognition & Exclusion of actors & Audit committees \\
\hline
\end{tabular}

Second, the paper shows that the definition of financial literacy unfolds in a fundamentally different manner in the empirical cases. In the surveys, the definition of financial literacy is presented as a non-controversial problem in which the solutions are set and agreed upon. As a result, the autonomous model drives the actors to identify deviations from a skillbased literacy norm, i.e., pointing out areas where financial literacy is absent. In the AC case, the process of unfolding financial literacy is the reverse. Here financial literacy is referred to as a something that is indeed present but is more porous in character. The financial literacy of an AC member is not configured by identifying what is lacking or deviating from a norm. In other words, whereas the surveys framed the problem as a question of spotting financial illiteracy, the regulation of the audit committees approached it as being a matter of differentiating levels of literacy. This paper argues, and perhaps in contrast with New Literacy Studies, that the autonomous model is of paramount significance as a way to introduce the problems of financial literacy. To mobilise resources to solve a problem, one initially needs to start out from an autonomous definition of the problem that reflects an overarching problematisation.

Third, whether a phenomenon is framed either as something that is there (albeit not explicitly specified) or as something that is not there entails different consequences in terms of solutions. The findings show that the measures in the audit committee case, on the one hand, are directed towards specifying criteria so that financial literacy can be identified. This clear identification, in turn, would make it possible to exclude some actors by disqualifying them from serving as AC members. Although some of our respondents were not altogether convinced of the fruitfulness of this exclusion, the regulations suggest that the demands for financial literacy in this context might not be in the public interest. In the highschool tour, however, the ambition is to include young people in society. The problem of exclusion is stabilised through the autonomous model of financial literacy, which defines it as a societal problem. However, the efforts to remedy this problem are framed as an invitation in which the high-school students are asked to reflect on issues related to financial literacy and not to the definitions suggested by the autonomous model that appears in the surveys. The explicit argument for financial education in general and the high-school tour in particular is to promote and foster literacy wherever it is absent, with a goal of including the illiterates in society and helping them to become the full-fledged citizens that society needs. Hence, whereas the AC case is concerned with how financial literacy is recognised, the latter is preoccupied with how it should be constructed.

In Table 1, the paper's findings are summarised according to the line of argument outlined above.

This paper is an attempt to problematise the previous research on financial literacy and offers an alternative viewpoint to understand its definition(s) and practices. In contrast to the dominant approach of viewing financial literacy as a phenomenon that can be acted upon and solved by means of technical skills, this paper draws on the insights of the New Literacy Studies to emphasise the situated conditions of how to understand financial literacy and the various ways in which it unfolds. Studies on financialisation acknowledge that accounting and finance are ever present and are to be found in places outside of the conventional idea of the organisation (Neu and Graham, 2006). This paper contributes to this (limited) research by investigating how financial literacy is formulated in different social settings.

Although this study is framed in the financial literacy/financialisation discourse, it also sets the stage for further research into how financial literacy interplays with the consumption of accounting information. The effects of accountingisation, for example on non-accountants (see e.g., Kurunmäki, 2004), have been problematised. However, accounting information is typically viewed either as being appropriated or dismissed rather than as being selectively made sense of. Both empirical cases show that financial literacy is a capacity that can always be contested and does not always "come first" (Rogers, 2001). More to the point, rather than presupposing that actors have a reasonable knowledge of business and economic activities, that they review and analyse information with diligence (IASB, 2010) and that they can be configured as rational economic decision makers (Young, 2006), accounting research might benefit from investigations into the interplay between skills and context and how accounting literacy is constructed and recognised to include and exclude actors from speaking and reading 'Accountish'. This study shows that for most consumers of financial information, accounting is, if anything, a second language. This perspective, we argue, opens up a possible venue of research that extends beyond the studies of how accounts are produced to study the ways in which accounts are (not) consumed.

\section{Acknowledgements}

First, we owe the editors and the two anonymous reviewers a word of gratitude as their suggestions have improved the paper significantly; in addition, we are grateful for the critical comments that we have received along the way from our colleagues at the Stockholm/Uppsala Musica Research Group. We also wish to acknowledge the financial support granted by Svenska Handelsbanken that made this research concept achievable. 


\section{References}

Ahrens T, Chapman CS. Management accounting as practice. Accounting Organizations and Society 2007;32:1-27.

Almenberg J, Widmark O. Numeracy, financial literacy and participation in asset markets. April 22, 2011. Available at SSRN: http://ssrn.com/abstract=1756674 or http://dx.doi.org/10.2139/ssrn.1756674 [accessed 08.08.12].

Andersson T, Gleadle PMR, Haslam C. Bio-pharma: a financialized business model. Critical Perspectives on Accounting 2010;21:631-41.

Atkinson A. Evidence of impact: an overview of financial education evaluations. Consumer Research No. 68. London: FSA; 2008.

Banks J, Oldfield Z. Understanding pensions: cognitive function, numerical ability and retirement saving. Fiscal Studies 2007;28(2):143-70.

Barton D, Hamilton M. Introduction: exploring situated literacies. In: Barton D, Hamilton M, Ivanic R, editors. Situated literacies: reading and writing in context. London: Routledge; 2000. p. 7-15.

Bay C. Framing financial responsibility: an analysis of the limitations of accounting. Critical Perspectives on Accounting 2011a;22:593-607.

Bay C. Makeover accounting: the financial edutainment of everyday life. In: Unpublished paper presented at the Critical Perspectives on Accounting Conference. Clearwater, Florida, 11-12 July; 2011.

Bédard J, Gendron Y. Strengthening the financial reporting system: can audit committees deliver? International Journal of Auditing $2010 ; 14: 174-210$.

Belfrage C. Towards 'universal financialisation' in Sweden? Contemporary Politics 2008;14:277-96.

Benston GJ, Hartgraves AL. Enron: what happened and what we can learn from it. Journal of Accounting and Public Policy 2002;21:105-27.

Blue Ribbon Committee. Report and recommendations of the Blue Ribbon Committee on improving the effectiveness of corporate audit committees. Stamford, Connecticut; 1999.

Carter EE. A simultaneous equation approach to financial planning: comment. The Journal of Finance 1973;28:1035-8.

Clarke J. A new kind of symmetry: actor-network theories and the New Literacy Studies. Studies in the Education of Adults 2002;34:107-22.

de Meza D, Irlenbusch B, Reyniers D. Financial capability: a behavioural economics perspective. Consumer Research No. 69. London: FSA; 2008.

Epstein GA, editor. Financialization and the world economy. Cheltenham: Edward Elgar Publishing; 2005.

European Commission. Eighth Directive. 2006/43/EEC. 2006.

European Commission. Bulletin of the European Union 12-2007. 2007.

Finansinspektionen. Hushållens ekonomiska förmåga: en studie i hur hushållen klarar sin ekonomi, 2007-06-27. Stockholm; 2007.

Finansinspektionen. Hushållens finansiella förmåga: en studie av svenska hushålls privatekonomi. Rapport 2009:11. Stockholm; 2009.

Finansinspektionen, Konsumentverket, Kronofogden. Koll på cashen: tre myndigheter, En skolturné. Broschure; 2008.

Finlayson A. Financialisation financial literacy and asset-based welfare. The British Journal of Politics \& International Relations 2009;11:400-21.

Fox J, Bartholomae S, Lee J. Building the case for financial education. Journal of Consumer Affairs 2005;39:195-214.

Freire P, Macedo D. Literacy: reading the word and the world. Hadley, MA: Bergin and Garvey; 1987.

Froud J, Johal S, Williams K. Financialisation and the coupon pool. Capital \& Class Conference Socialist Economist 2002;119-51.

Gee JP. Social linguistics and literacies: ideology in discourses. London: Falmer Press; 1990.

Gee JP. The New Literacy Studies: from 'socially situated' to the work of the social. In: Barton D, Hamilton D, Ivanivic R, editors. Situated literacies: reading and writing in context. London: Routledge; 2000. p. 180-96.

Gee JP. Social linguistics and literacies: ideology in discourses. London: Routledge; 2008.

Gee JP, Hull G, Lankshear C. The New Work order: behind the language of the new capitalism. Boulder, CO: Westview; 1996.

Gendron Y, Bédard J. On the constitution of audit committee effectiveness. Accounting Organizations and Society 2006;31:211-39.

Gleadle PMR, Haslam C. An exploratory study of an early stage R\&D-intensive firm under financialization. Accounting Forum 2010;34(1):54-65.

Gough PB. The new literacy: caveat emptor. Journal of Research in Reading 1995;18:79-86.

Greenfield C, Williams P. Financialization, finance rationality and the role of media in Australia. Media Culture \& Society 2007;29:415-33.

Hamilton M. Expanding the New Literacy Studies: using photographs to explore literacy as social practice. In: Barton M, Hamilton M, Ivanic R, editors. Situated literacies: reading and writing in context. London: Routledge; 2000.

Huston SJ. Measuring financial literacy. Journal of Consumer Affairs 2010;44:296-316.

IASB. Conceptual framework for financial reporting (IFRS Framework). 2010.

IOSCO. Principles on point of sale disclosure. Madrid: IOSCO/MS/12/2009; 2009.

Jackson M. Literacy. London: David Fulton Publishers; 1993.

Jappelli T. Economic literacy: an international comparison. The Economic Journal 2010;120:F429-51.

Johnson E, Sherraden MS. From financial literacy to financial capability among youth. Journal of Sociology and Social Welfare 2007;34:119-46.

Kurunmäki L. A hybrid profession: the acquisition of management accounting expertise by medical professionals. Accounting Organizations and Society 2004;29:327-47.

Langley P. Uncertain subjects of Anglo-American financialization. Cultural Critique 2007;65:67-91.

Langley P. The everyday life of global finance: saving and borrowing in Anglo-America. Oxford: Oxford University Press; 2008.

Lazonick W, O'Sullivan M. Maximizing shareholder value: a new ideology for corporate governance. Economy and Society 2000;29:13-35.

Lusardi A, Mitchell OS. Financial literacy and planning: implications for retirement wellbeing. University of Pennsylvania, Pension Research Council, Wharton School; 2006.

Lusardi A, Mitchell OS. Baby Boomer retirement security: the roles of planning, financial literacy, and housing wealth. Journal of Monetary Economics 2007;54:205-24.

Lyons AC, Chang Y, Scherpf EM. Translating financial education into behavior change for low-income populations. Financial Counseling and Planning 2006;17: 27-45.

Martin R. The financialization of daily life. Philadelphia: Temple University Press; 2002.

McSweeney B. The roles of financial asset market failure denial and the economic crisis: reflections on accounting and financial theories and practices. Accounting Organizations and Society 2009;34:835-48.

Micklethwait A. Greed and corporate failure: the lessons from recent disasters. Houndmills, Basingstoke, Hampshire: Palgrave Macmillan; 2006.

Neu D, Graham C. The birth of a nation: accounting and Canada's first nations, 1860-1900. Accounting Organizations and Society 2006;31:47-76.

Odell M. Regeringen satsar på privatekonomisk folkbildning, Press release, 23 November 2007. Stockholm: Swedish Ministry of Finance; 2007.

OECD. Improving financial literacy: analysis of issues and policies. OECD Publishing; 2005.

OECD. The importance of financial education. OECD Policy Brief; 2006.

OECD. Improving financial education and awareness on insurance and private pension. OECD Publishing; 2008.

OECD. The OECD project on financial education. OECD Publishing; 2009.

Oehler A, Werner C. Saving for retirement: a case for financial education in Germany and UK? An economic perspective Journal of Consumer Policy 2008;31: 253-83.

Remund DL. Financial literacy explicated: the case for a clearer definition in an increasingly complex economy. Journal of Consumer Affairs 2010;44:276-95.

Rogers A. Afterword: problematising literacy and development. In: Street B, editor. Literacy and development: ethnographic perspectives. London: Routledge; 2001. p. 205-22.

Street B. Literacy in theory and practice. Cambridge: Cambridge University Press; 1984.

Street B. Preface. In: Prinsloo M, Breier M, editors. The social uses of literacy: theory and practice in contemporary South Africa. Sached: John Benjamins; 1996. p. $1-10$.

Street B. The implications of the 'New Literacy Studies' for literacy education. English in Education 1997;31:45-59.

Street B. Introduction. In: Street B, editor. Literacy and development: ethnographic perspectives. London: Routledge; 2001. 
Street B. What's 'new' in New Literacy Studies? Critical approaches to literacy in theory and practice Current Issues in Comparative Education 2003;5:77-91. The World Bank. The case for financial literacy in developing countries. 2009.

Turley S, Zaman M. Audit committee effectiveness: informal processes and behavioural effects. Accounting Auditing \& Accountability Journal 2007;20:765-88. Van Rooij M, Lusardi A, Alessie R. Financial literacy and stock market participation. Cambridge, MA, USA: National Bureau of Economic Research; 2007.

Verschoor CC. Audit committee essentials. Hoboken, New Jersey: John Wiley \& Sons; 2008.

Williams T. Empowerment of whom and for what? Financial literacy education and the new regulation of consumer financial services Law \& Policy 2007;29: 226-56.

Willis LE. Evidence and ideology in assessing the effectiveness of financial literacy education. San Diego Law Review 2009;46:415-58.

Young JJ. Making up users. Accounting Organizations and Society 2006;3:579-600. 